\title{
Interaction between climate and management on beta diversity components of vegetation in relation to soil properties in arid and semi-arid oak forests, Iran
}

\author{
Heydari MEHDI ${ }^{1 *}$, Aazami FATEMEH ${ }^{1}$, Faramarzi MARZBAN ${ }^{2}$, Omidipour REZA $^{3}$, Bazgir \\ MASOUD $^{4}$, Pothier DAVID ${ }^{5}$, Prévosto BERNARD ${ }^{6}$ \\ ${ }^{1}$ Department of Forest Science, College of Agriculture, Ilam University, Ilam 6939177111, Iran; \\ ${ }^{2}$ Department of Rangeland and Watershed Management, College of Agriculture, Ilam University, Ilam 6939177111, Iran; \\ ${ }^{3}$ Department of Rangeland and Watershed Management, College of Natural Resources and Earth Sciences, Shahrekord \\ University, Shahrekord 14536-33143, Iran; \\ ${ }^{4}$ Department of Soil Science, College of Agriculture, Ilam University, Ilam 6939177111, Iran; \\ ${ }^{5}$ Department of Wood and Forest Sciences, Centre for Forest Research, Laval University, Quebec, QC G1V 0A6, Canada; \\ ${ }^{6}$ Irstea-National Research Institute of Science and Technology for Environment and Agriculture, Aix-en-Provence 13128, \\ France
}

\begin{abstract}
This study aimed to investigate the interaction between regions with different climatic conditions (arid vs. semi-arid) and management (protected vs. unprotected) on the turnover and nestedness of vegetation in relation to physical, chemical and biological properties of soils in the Ilam Province of Iran. In each of the two regions, we sampled 8 sites (4 managed and 4 unmanaged sites) within each of which we established 4 circular plots $\left(1000 \mathrm{~m}^{2}\right)$ that were used to investigate woody species, while two micro-plots $(1 \mathrm{~m} \times 1 \mathrm{~m})$ were established in each $1000-\mathrm{m}^{2}$ plot to analyze herbaceous species. In each sample unit, we also extracted three soil samples $(0-20 \mathrm{~cm}$ depth) for measuring soil properties. The results indicated that the interaction between region and conservational management significantly affected the percent of canopy cover of Persian oak (Quercus brantii Linddl), soil respiration, substrate-induced respiration, as well as beta and gamma diversities and turnover of plant species. The percent of oak canopy cover was positively correlated with soil silt, electrical conductivity, available potassium, and alpha diversity, whereas it was negatively correlated with plant turnover. In addition, plant turnover was positively related to available phosphorus, while nestedness of species was positively related to organic carbon and total nitrogen. According to these results, we concluded that physical, chemical, and biological characteristics of limited ecological niche generally influenced plant diversity. Also, this study demonstrated the major contribution of the beta diversity on gamma diversity, especially in semi-arid region, because of the higher heterogeneity of vegetation in this area.
\end{abstract}

Keywords: climatic conditions; conservation management; beta diversity; oak forests; physical-chemical property; semi-arid region

Citation: Heydari MEHDI, Aazami FATEMEH, Faramarzi MARZBAN, Omidipour REZA, Bazgir MASOUD, Pothier DAVID, Prévosto BERNARD. 2019. Interaction between climate and management on beta diversity components of vegetation in relation to soil properties in arid and semi-arid oak forests, Iran. Journal of Arid Land, 11(1): 43-57. https://doi.org/10.1007/s40333-018-0024-z

\footnotetext{
*Corresponding author: Heydari MEHDI (E-mail: m_heydari23@yahoo.com; m.heidari@ilam.ac.ir)

Received 2017-11-14; revised 2018-05-15; accepted 2018-08-03

C Xinjiang Institute of Ecology and Geography, Chinese Academy of Sciences, Science Press and Springer-Verlag GmbH Germany, part of Springer Nature 2019
} 


\section{Introduction}

Forest ecosystems have a critical role to mitigate soil loss and erosion, regulate weather, and maintain habitats and biodiversity (Fathizadeh et al., 2017). Forest degradation and/or destruction had many negative effects on plant and soil microorganism diversity and composition (Moradi Behbahani et al., 2017; Yacht et al., 2017) and soil properties (Feng et al., 2017). Conservation management can be a key factor in preventing worldwide destruction of forest ecosystems and promoting the sustainability of these valuable resources.

Biodiversity indices are generally used to assess and evaluate ecosystem degradation (Wilson and Tilman, 2002). However, with the increasing importance of biodiversity conservation, the use of new and effective methods to investigate plant biodiversity has become increasingly popular. Diversity partitioning (additive vs. multiplicative) is one of these methods that was frequently used during the two recent decades by ecologists devoted to biodiversity conservation (Erfanzadeh et al., 2015). According to this method, total regional diversity can be additively partitioned $(\gamma=\alpha+\beta$; Lande, 1996) or multiplied $(\gamma=\alpha \times \beta)$ into within (alpha diversity) and among (beta diversity) components across different spatial/temporal scales (Crist et al., 2003). The additive partitioning method has been increasingly used in rangeland and forest studies in relation to plant species diversity (Chávez and Macdonald, 2012; Zhang et al., 2014; Erfanzadeh et al., 2015; Schulze et al., 2016).

Beta diversity is an important biodiversity index that is defined as the variation in community composition from one place to another. Baselga (2010) mathematically demonstrated that beta diversity can be decomposed in two main processes: turnover and nestedness. Spatial turnover is defined as the continuous or sudden replacement of species along an environmental gradient due to environmental pressure, climate change or competition (Baselga, 2010; Lafage et al., 2015). For its part, nestedness refers to communities in which species composing a low-diversity community are a subset of a high-diversity community that was subjected to species migration or extinction (Calderón-Patrón et al., 2013). By analyzing beta diversity components and their respective contribution to the total beta diversity, we can detect the main mechanism involved in changes in community composition.

Semi-arid forests of the Zagros Mountains are dominated by Persian oak (Quercus brantii Linddl) and cover an area of about $5 \times 10^{6} \mathrm{hm}^{2}$ (40\% of Iranian forests; Sagheb-Talebi et al., 2014). They form one of the most important ecosystems of Iran due to their high level of biodiversity and the presence of endemic species (Marvi Mohadjer, 2005). The Zagros region has a great impact on the livelihood of people due to the dependency of people on local resources (Salehi et al., 2013). Unfortunately, during the last three decades, the vegetation of the Zagros forests was highly degraded due to incorrect management practices and human activities such as human-caused fire, over-grazing, excessive cutting, firewood harvesting, and land use changes (Heydari et al., 2016).

While forest degradation could create important changes in vegetation composition and forest structure, forest soils can also be impacted. Soils are an important constituent of ecosystems and play a critical role in the development of forest vegetation, which, in turn, have noticeable effects on the development of physical, chemical and biological soil properties (Onyekwelu et al., 2006; Kooch et al., 2007; Wang, 2007).

Biodiversity conservation in the Zagros forests should take advantage of new management practices to help reduce the progression of its degradation caused by drought-induced oak mortality. Conservation plan including exclosures is one management solution that was effective in the Zagros forests (Heydari et al., 2013a). Tárrega et al. (2009) reported that different management regimes in dehesa ecosystems (grazed, ungrazed, ungrazed with shrub cutting) had a critical effect on soil properties and vegetation in oak (Q. pyrenaica) stands, and that conservational practices led to the improvement in soil fertility. This is in accordance with the results that conservational practices (grazed vs. ungrazed) had positive effects on soil properties and vegetation (Strandberg et al., 2005). In addition, Sheklabadi et al. (2007) observed that in areas degraded by grazing, the amounts of organic carbon, total nitrogen, and microbial 
respiration were lower than in non-degraded areas.

Climate is another factor that has profound effects on vegetation diversity and composition as well as on soil properties (Kardol et al., 2010). Climatic factors, particularly temperature and precipitation, affect the formation and evolution of soils (Binkley and Fisher, 2012), the accumulation of organic carbon (Wang et al., 2013), the cycling rate of nutrients (Auyeung et al., 2013) and the soil biological activity (Sardans and Peñuelas, 2005; Steinweg et al., 2013).

Due to the interaction between soil characteristics, climatic conditions and plant species (von Lutzow and Kogel-Knabner, 2009; Toure et al., 2015; Mirzaei and Moradi, 2017), changes in plant species diversity and composition between regions with different climatic conditions are expected. On the other hand, plant communities and their characteristics such as life form spectra gradually reach equilibrium with climatic conditions to form so-called climatic climax communities (Raunkiaer, 1934).

The effects of forest degradation and management strategies on plant diversity and soil attributes have been recently investigated in the Zagros forest of Iran (Parma et al., 2010; Heydari et al., 2017). However, no study has addressed the effects of climate with or without interaction with management practices on diversity components (alpha and beta diversity) as well as on beta diversity components (turnover and nestedness). This study aimed to fill this gap by evaluating the effects of climate, management strategies, and their interaction on soil physical, chemical, and biological properties as well as on biodiversity components.

\section{Materials and methods}

\subsection{Study area}

This study took place in managed and unmanaged (see details below) forests dominated by Persian oak (Quercus brantii Linddl) in western Iran. These forests were located in two regions with different climatic conditions (Fig. 1). According to the classification system of de Martonne (1925), the climates of these regions are both Mediterranean, but semi-arid Dalab region is characterized by annual precipitation of $590 \mathrm{~mm}$ and annual mean temperature of $16.7^{\circ} \mathrm{C}$, while the precipitation and annual mean temperature of arid Koshk region are $408 \mathrm{~mm}$ and $18.5^{\circ} \mathrm{C}$, respectively. These regions are both part of the Zagros Mountains, and the geology and the pedogenesis of the two regions are similar. Calcareous soils with a clay loamy texture, dominate the soils of these regions.

In each region, we selected 4 managed and 4 unmanaged sites that were described by Heydari et al. (2013b). In managed sites, a 20-year period of strict conservation was applied following long-term human disturbances. For their part, unmanaged sites were never protected against long-term anthropogenic land degradation such as tree and shrub cutting for firewood and development of arable lands as well as animal husbandry (Heydari et al., 2013b). The vegetation of managed sites of Dalab (MD) was dominated by Cerasus microcarpa, Daphne mucronata, Acantholimon bromoifoliu, Teucrium polium, Alyssum marginatum, Centaurea depressa, Centaurea amadanensis, and Centaurea koeieana. In unmanaged sites of Dalab (UMD), the dominant vegetation was composed of Capparis parviflora, Astragalus fasciculifolius, Astragalus (Leucocercis) curviflorus, Bromus tomentellus, Gundelia tournefortii, Erodium cicotarium, Stellaria media, and Valerianella dactylophylla. In managed sites of Koshk (MK), the dominant species were Pistacia khinjuk, Amygdalus lycioides, Populus euphratica, Medicago rigidula, Sinapis arvensis, Trifolium purpureum, Ziziphora capitata, and Anthemis pseudocotula. Finally, in unmanaged sites of Koshk (UMK), the vegetation was dominated by Nerium oleander, Vitex pseudo-negundo, Medicago rigidula, Sinapis arvensis, Phlomis olivieriv, Crepis katschyana, and Scabiosa leucactic (Aazami, 2016).

\subsection{Experimental design and data collection}

The combination of our two regions ( $\mathrm{D}=\mathrm{Dalab}, \mathrm{K}=\mathrm{Kosh}$ ) with the two types of management $(\mathrm{M}=$ managed, $\mathrm{UM}=$ unmanaged) resulted in four treatments $(\mathrm{MD}, \mathrm{UMD}, \mathrm{MK}$, and $\mathrm{UMK})$ and with different climatic conditions (semi-arid Dalab region vs. arid Koshk region). In each 


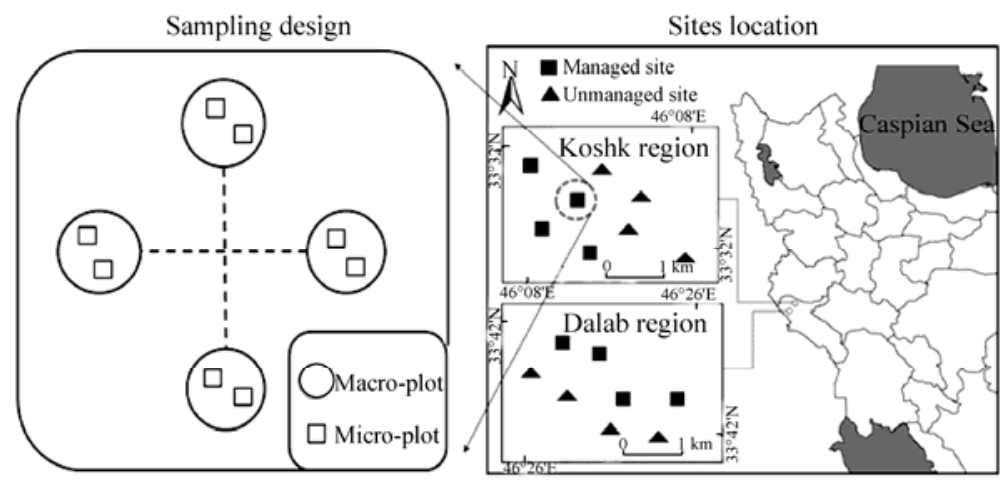

Fig. 1 Study area location and layout of sampling method design

treatment, we selected 4 independent sites that were considered as replicates. However, to decrease variability, we selected geographically adjacent sites in each region. In the center of each site, we used a systematic sampling method to establish a cluster of four circular, the $1000-\mathrm{m}^{2}$ plots located $100 \mathrm{~m}$ apart (Fig. 1). These plots were used to estimate the percent cover of all woody species while two squared $1-\mathrm{m}^{2}$ micro-plots, located within each main plot, were randomly established to investigate herbaceous species (each species was given a value of abundance) in May 2015. In total, we have 16 sampling sites ( 8 in Koshk and 8 in Dalab), 64 macro-plots $\left(1000 \mathrm{~m}^{2}\right)$ and 128 micro-plots.

\subsection{Soil sampling and laboratory methods}

We extracted soil samples at 0-20 cm depth in May 2015. Soil physical, chemical, and biological properties were determined from composite samples, each consisting of three sub-samples that were gathered from three randomly selected points in each main plot (for a total of 64 composite soil samples). Soils were sieved (2-mm mesh) to remove roots and debris prior to laboratory analyses and divided into two subsamples.

The first subsample was air-dried for measuring physical and chemical properties. Soil texture was measured using a hydrometer (Bouyoucos, 1962). Soil organic carbon (SOC) was determined by dichromate oxidation using the Walkley-Black method (Nelson and Sommers, 1982). Soil pH and electrical conductivity (EC) were electrometrically determined (in $\mathrm{H}_{2} \mathrm{O}, 2: 1 \mathrm{v} / \mathrm{m}$ ) with a conductivity probe in filtered extracts (Kalra and Maynard, 1991). Soil cation exchange capacity (CEC) was determined following extraction in buffered sodium acetate $(\mathrm{NaOAc}$, at $\mathrm{pH} 8.2$; Sumner and Miller, 1996). Total nitrogen (TN) was measured by Kjeldahl digestion (Bremner, 1996). Available phosphorus (Pava) was determined using the method of Bray and Kurtz (1945). Available potassium (Kava) was determined following ammonium acetate $(\mathrm{pH} 7.0)$ extraction and quantified by flame photometry (Black, 1986). Lime percentage, expressed using the total neutralizing value (TNV), was determined using the $\mathrm{NaOH}$ titration method.

The second subsample was maintained at field moisture and stored at $4{ }^{\circ} \mathrm{C}$ for subsequent measurements of soil microbial activity. Soil basal respiration (BR) was measured by trapping and quantifying $\mathrm{CO}_{2}$ that was emitted from soil samples over a 5-d period (Alef and Nannipieri, 1995). Substrate-induced respiration (SIR) was determined using glucose (1\%) as the substrate and the evolved $\mathrm{CO}_{2}$ was determined after $8 \mathrm{~h}$ incubation. Evolved $\mathrm{CO}_{2}$ was adsorbed in $1 \mathrm{M}$ $\mathrm{NaOH}$ and measured by $0.1 \mathrm{M} \mathrm{HCl}$ titration (Anderson and Domsch, 1978).

Additional undisturbed soil cores distributed in the four treatments were collected for the determination of bulk density (BD) in the $0-15 \mathrm{~cm}$ mineral layer (Blake and Hartge, 1986). Soils were immediately sieved $(2 \mathrm{~mm})$ and kept in a plastic box to avoid evaporation. Soil water content (SWC, water mass/soil dry mass) was gravimetrically measured (oven-drying at $105^{\circ} \mathrm{C}$ for 24 h; Famiglietti et al., 1998)

\subsection{Diversity partitioning}

To estimate the diversity components, we used the additive partitioning method as shown in Equation 1 (Crist et al., 2003): 


$$
\gamma=\alpha_{1}+\sum_{i=1}^{m} \beta_{i}
$$

where $\gamma$ is the total species diversity; $m$ is the number of scales; $\alpha_{1}$ is the average diversity within sample units in each site; and $\beta_{i}$ is the beta diversity at each scale $i$. This method enabled us to estimate the total species richness in each region $(\gamma)$, which was partitioned into $\alpha_{1}$ (the mean number of species found per $1-\mathrm{m}^{2}$ plot) and $\beta_{1}$ (the difference between $\alpha_{1}$ and $\gamma$ sites, in which $\gamma$ site was the total species richness of each site).

Then, we additively partitioned the beta diversity into two components, i.e., the spatial turnover and nestedness. To do this, we used the method suggested by Baselga (2010), which is based on the multiple dissimilarity derived from the Sørensen coefficient of dissimilarity (Baselga, 2010). This analysis was performed using the beta part package (Baselga and Orme, 2012) within the R software (R Development Core Team, 2013).

\subsection{Statistical analysis}

First, the normality of each variable was verified using the Kolmogorov-Smirnov test as well as variance homogeneity (Levene Test). Mathematical transformations of data were used when necessary to correct deviations from normality and heterogeneity of variance. Then we used two-way ANOVAs to detect significant differences between variable means associated with treatments, regions, and the interaction between treatments and regions. If the two-way ANOVAs detected significant differences, we applied a Duncan test for pairwise comparisons. Pearson's correlation coefficients were calculated to investigate possible relationships between oak cover, soil properties, and diversity components. Finally, relationships between beta diversity components and soil factors were analyzed using linear regressions. All analyses were performed with the R statistical software.

\section{Results}

\subsection{Effects of management measures and climate on oak canopy cover, soil properties, diversity components}

The results showed that management (protected vs. unprotected), climatic conditions (arid vs. semi-arid) and their interaction had a significant $(P<0.05)$ effects on oak canopy cover (Table 1). These variables also produced significant effects on soil water content, silt, BR and SIR. However, for TNV, clay, Pava, Kava, total N, and SOC, only the effects of management and climatic conditions were significant, while their interaction was not significant (Table 1). The percent of sand and BD were solely affected by management, while EC and $\mathrm{pH}$ were affected only by climatic conditions.

Diversity components (alpha, beta, and gamma) and beta diversity components (turnover and nestedness) showed different trends in relation to management, climatic conditions, and their interaction (Table 1). We detected significant effects of management and climatic conditions for all diversity components but a significant influence of the interaction was revealed only for beta and gamma diversity as well as turnover. Therefore, the effects of management on alpha diversity and nestedness were similar across the two regions (Table 1).

\subsection{Oak canopy cover and soil physical-chemical properties}

Oak canopy cover was significantly higher in Dalab region than in Koshk region. This variable was also significantly higher in managed than in unmanaged plots for both Dalab and Koshk regions (Table 2). Kava was higher in Dalab region than in Koshk region while the reverse was true for Pava.

EC was higher in unmanaged than in managed plots for Koshk region while it was lower in Dalab region within which no significant differences were found between managed and unmanaged plots. Soil pH was unaffected by management in both regions but was higher in Koshk region than in Dalab region. Clay content was significantly higher in MD than in the other treatments, whereas silt content was higher in MK. Sand content was higher in unmanaged plots but the difference was significant in Koshk region only. The treatment order for total nitrogen and organic matter contents was $\mathrm{MD}>\mathrm{UMD}=\mathrm{MK}>\mathrm{UMK}$, whereas that of $\mathrm{TNV}$ was 
$\mathrm{UMK}>\mathrm{UMD}>\mathrm{MK}>\mathrm{MD}$ (Table 2). Soil water content and BD were highest in managed plots for Dalab region and in unmanaged plots for Koshk region, respectively.

Table 1 Results of two way-ANOVA ( $F$-value and significance level) testing for regions with different climatic conditions and managements on oak canopy cover percentage, soil properties, diversity components (alpha, beta and gamma) and beta diversity components (spatial turnover and nestedness)

\begin{tabular}{|c|c|c|c|c|}
\hline & Variable & Management & Climate & Management $\times$ Climate \\
\hline \multirow{6}{*}{$\begin{array}{l}\text { Oak canopy cover } \\
\text { and soil physical } \\
\text { properties }\end{array}$} & Oak canopy cover & $11.662^{* *}$ & $8.396^{* *}$ & $6.040^{*}$ \\
\hline & $\mathrm{BD}$ & $1.037^{*}$ & 2.846 & 2.732 \\
\hline & Soil water content & $15.859^{* *}$ & $11.017^{* *}$ & $5.475^{*}$ \\
\hline & Sand & $5.988^{*}$ & 0.828 & 0.198 \\
\hline & Clay & $3.562^{*}$ & $0.608^{*}$ & 0.007 \\
\hline & Silt & $0.463^{*}$ & $3.795^{* *}$ & $0.372^{*}$ \\
\hline \multirow{7}{*}{$\begin{array}{l}\text { Soil chemical } \\
\text { properties }\end{array}$} & TNV & $26.447^{* * *}$ & $14.393^{* *}$ & 2.084 \\
\hline & SOC & $62.331^{* * *}$ & $43.721^{* * *}$ & 0.388 \\
\hline & Pava & 13.529 & $394.731^{* * *}$ & 0.438 \\
\hline & $\mathrm{EC}$ & 1.752 & $6.209^{*}$ & $5.100^{*}$ \\
\hline & $\mathrm{pH}$ & 4.134 & $62.152^{* * *}$ & 1.145 \\
\hline & $\mathrm{TN}$ & $62.331^{* * *}$ & $43.721^{* * *}$ & 0.388 \\
\hline & Kava & 0.219 & $43.522^{* * *}$ & 0.005 \\
\hline \multirow{2}{*}{$\begin{array}{l}\text { Soil biological } \\
\text { variables }\end{array}$} & $\mathrm{BR}$ & $177.920^{* * *}$ & $368.656^{* * *}$ & $112.515^{* * *}$ \\
\hline & SIR & $105.622^{* * *}$ & $162.689^{* * *}$ & $33.996^{* * *}$ \\
\hline \multirow{5}{*}{ Diversity } & Alpha diversity & $160.163^{* * *}$ & $4.379^{*}$ & 0.054 \\
\hline & Beta diversity & $136.289^{* * *}$ & $39.472^{* * *}$ & $37.768^{* * *}$ \\
\hline & Gamma diversity & $370.559^{* * *}$ & $20.931^{* * *}$ & $35.477^{* * *}$ \\
\hline & Turnover & $11.626^{* *}$ & $183.214^{* * *}$ & $42.374^{* * *}$ \\
\hline & Nestedness & $13.636^{* *}$ & $4.909^{*}$ & 2.182 \\
\hline
\end{tabular}

Note: BD, bulk density; TNV, total neutralizing value; SOC, soil organic carbon; Pava, available phosphorus; EC, electrical conductivity; TN, total nitrogen; Kava, available potassium; BR, basal respiration; SIR, substrate induced respiration. ${ }^{* * *},{ }^{* *}$ and ${ }^{*}$ indicate the significances at $P<0.001, P<0.01$ and $P<0.05$ levels, respectively.

\subsection{Soil biological variables}

The mean values of BR and SIR in Dalab region were higher than those in Koshk region but the influence of management was significant in both regions with higher values of BR and SIR in managed than in unmanaged plots (Table 2).

\subsection{Alpha, beta and gamma diversity and plant beta diversity components}

Alpha, beta and gamma diversity values were higher in managed than in unmanaged plots in both regions. Diversity values were significantly higher (beta and gamma) or similar (alpha) between managed Dalab and managed Koshk regions, whereas no significant differences were detected between the two regions in unmanaged plots (Fig. 2a).

Between the two components of the beta diversity, spatial turnover was largely higher than nestedness in each treatment (Fig. 2b). Turnover significantly decreased according to the following order $\mathrm{MD}>\mathrm{UMD}>\mathrm{UMK}>\mathrm{MK}$. By contrast, nestedness was lowest in MD while there were no significant differences among the other treatments.

\subsection{Relationships between oak canopy cover, soil properties, and diversity components}

The oak canopy cover was positively correlated with silt, $\mathrm{pH}$, Kava, and alpha diversity, while it was negatively correlated with spatial turnover (Table 3 ).

\subsection{Linear regressions between beta diversity components and soil properties}

There were strong negative relationships between spatial turnover and BD, EC, $\mathrm{pH}$, and Pava (Fig. 3). By contrast, spatial turnover was strongly and positively related to Kava, BR, and SIR 
(Fig. 3).

The nestedness of plant species was significantly and positively related to TNV, and negatively related to SWC, SOC, TN, BR, and SIR (Fig. 4).

Table 2 Oak canopy cover, soil physical-chemical and microbial properties measured in different regions

\begin{tabular}{|c|c|c|c|c|}
\hline \multirow{2}{*}{ Variable } & \multicolumn{2}{|c|}{ Koshk } & \multicolumn{2}{|c|}{ Dalab } \\
\hline & Managed & Unmanaged & Managed & Unmanaged \\
\hline Oak canopy cover $(\%)$ & $10.18 \pm 2.33^{b}$ & $7.52 \pm 1.32^{\mathrm{b}}$ & $20.13 \pm 3.92^{\mathrm{a}}$ & $8.94 \pm 1.22^{\mathrm{b}}$ \\
\hline $\mathrm{BD}\left(\mathrm{g} / \mathrm{cm}^{3}\right)$ & $1.37 \pm 0.02^{\mathrm{b}}$ & $1.48 \pm 0.03^{\mathrm{a}}$ & $1.36 \pm 0.01^{\mathrm{b}}$ & $1.38 \pm 0.02^{\mathrm{b}}$ \\
\hline Sand $(\%)$ & $47.87 \pm 1.61^{\mathrm{b}}$ & $55.65 \pm 2.45^{\mathrm{a}}$ & $48.58 \pm 1.24^{\mathrm{b}}$ & $52.71 \pm 2.34^{\mathrm{ab}}$ \\
\hline Clay (\%) & $27.71 \pm 1.51^{\mathrm{b}}$ & $24.43 \pm 0.51^{\mathrm{b}}$ & $31.04 \pm 2.16^{\mathrm{a}}$ & $27.04 \pm 3.2^{\mathrm{b}}$ \\
\hline Silt (\%) & $24.42 \pm 1.64^{\mathrm{a}}$ & $19.92 \pm 2.04^{\mathrm{b}}$ & $20.38 \pm 1.24^{\mathrm{b}}$ & $20.25 \pm 0.91^{\mathrm{b}}$ \\
\hline SWC (\%) & $40.87 \pm 0.59^{b}$ & $38.06 \pm 0.85^{\mathrm{b}}$ & $50.54 \pm 3.09^{\mathrm{a}}$ & $39.74 \pm 0.99^{b}$ \\
\hline $\mathrm{pH}$ & $7.38 \pm 0.01^{\mathrm{a}}$ & $7.37 \pm 0.01^{\mathrm{a}}$ & $7.14 \pm 0.04^{b}$ & $7.20 \pm 0.01^{\mathrm{b}}$ \\
\hline $\mathrm{EC}(\mathrm{dS} / \mathrm{m})$ & $0.38 \pm 0.03^{b}$ & $0.52 \pm 0.03^{\mathrm{a}}$ & $0.29 \pm 0.01^{\mathrm{c}}$ & $0.32 \pm 0.01^{\mathrm{c}}$ \\
\hline Total nitrogen (\%) & $0.23 \pm 0.010^{\mathrm{b}}$ & $0.18 \pm 0.010^{\mathrm{c}}$ & $0.33 \pm 0.010^{\mathrm{a}}$ & $0.21 \pm 0.006^{\mathrm{b}}$ \\
\hline $\mathrm{SOC}(\%)$ & $3.37 \pm 0.31^{\mathrm{b}}$ & $2.81 \pm 0.55^{\mathrm{c}}$ & $5.72 \pm 0.32^{\mathrm{a}}$ & $3.55 \pm 0.11^{\mathrm{b}}$ \\
\hline TNV (\%) & $43.93 \pm 0.91^{\mathrm{b}}$ & $52.40 \pm 0.47^{\mathrm{a}}$ & $35.83 \pm 3.39^{c}$ & $48.85 \pm 1.87^{\mathrm{ab}}$ \\
\hline Kava (mg/kg) & $263.09 \pm 15.00^{\mathrm{bc}}$ & $169.80 \pm 8.47^{\mathrm{c}}$ & $400.79 \pm 17.56^{\mathrm{a}}$ & $387.67 \pm 39.55^{\mathrm{a}}$ \\
\hline Pava (mg/kg) & $9.95 \pm 0.07^{\mathrm{a}}$ & $9.09 \pm 0.13^{\mathrm{a}}$ & $7.60 \pm 0.21^{\mathrm{b}}$ & $7.07 \pm 0.05^{\mathrm{b}}$ \\
\hline $\mathrm{BR}\left(\mathrm{mg} \mathrm{CO} \mathrm{CO}_{2} \mathrm{C} /(\mathrm{kg}\right.$ soil $\left.\bullet \mathrm{d})\right)$ & $12.21 \pm 0.35^{\mathrm{c}}$ & $10.49 \pm 0.21^{\mathrm{c}}$ & $34.01 \pm 0.41^{\mathrm{a}}$ & $16.40 \pm 1.34^{\mathrm{b}}$ \\
\hline $\operatorname{SIR}\left(\mathrm{mg} \mathrm{CO}{ }_{2} \mathrm{C} /(\mathrm{kg}\right.$ soil $\left.\cdot \mathrm{d})\right)$ & $23.61 \pm 0.62^{b}$ & $21.84 \pm 1.48^{\mathrm{c}}$ & $49.40 \pm 1.95^{\mathrm{a}}$ & $24.58 \pm 1.46^{\mathrm{b}}$ \\
\hline
\end{tabular}

Note: BD, bulk density; SWC, soil water content; EC, electrical conductivity; SOC, soil organic carbon; TNV, total neutralizing value; Kava, available potassium; Pava, available phosphorus; BR, basal respiration; SIR, substrate induced respiration. Within rows, means with the same lowercase letters do not significantly differ at $P>0.05$ level. Mean \pm SE.

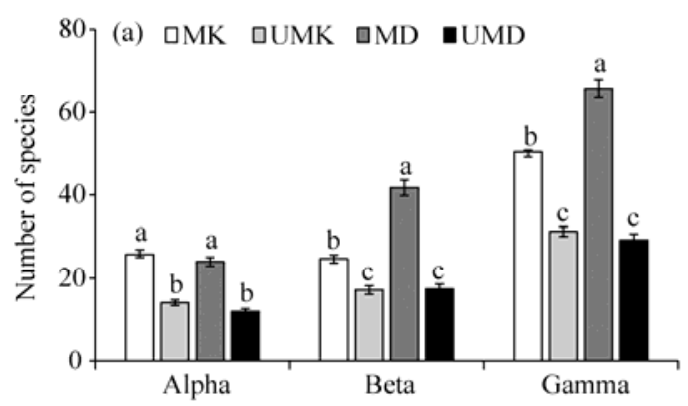

Diversity component

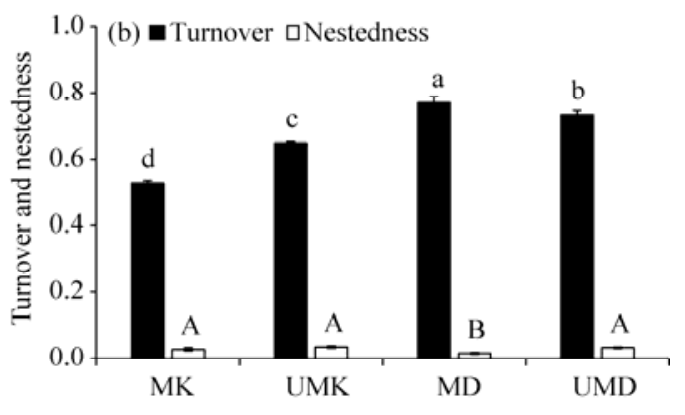

Treatment

Fig. 2 Variations of the diversity components according to treatments for (a) alpha, beta and gamma components and (b) turnover and nestedness. Bars indicate standard errors. MK, managed site of Koshk; UMK, unmanaged site of Koshk; MD, managed site of Dalab; UMD, unmanaged site of Dalab. Means with the same letters for a given diversity component (a) or different sites (b) are not significantly different based on Duncan's multiple range test $(P>0.05)$.

Table 3 Pearson's correlation coefficients between oak canopy cover and soil properties and diversity components

\begin{tabular}{|c|c|c|c|c|c|}
\hline Variable & $\begin{array}{l}\text { Oak canopy } \\
\text { cover }\end{array}$ & Variable & $\begin{array}{c}\text { Oak canopy } \\
\text { cover }\end{array}$ & Variable & $\begin{array}{c}\text { Oak canopy } \\
\text { cover }\end{array}$ \\
\hline $\mathrm{BD}$ & $-0.14^{\mathrm{ns}}$ & Pava & $0.14^{\mathrm{ns}}$ & Total nitrogen & $-0.02^{\text {ns }}$ \\
\hline SWC & $-0.08^{\mathrm{ns}}$ & Kava & $0.36^{*}$ & Alpha & $0.36^{*}$ \\
\hline Sand & $-0.23^{\mathrm{ns}}$ & TNV & $0.09^{\text {ns }}$ & Beta & $-0.28^{\mathrm{ns}}$ \\
\hline Clay & $-0.03^{\mathrm{ns}}$ & BR & $-0.25^{\mathrm{ns}}$ & Gamma & $-0.09^{\mathrm{ns}}$ \\
\hline Silt & $0.14^{*}$ & SIR & $-0.28^{\mathrm{ns}}$ & Spatial turnover & $-0.62^{*}$ \\
\hline $\mathrm{pH}$ & $0.32^{*}$ & $\mathrm{EC}$ & $0.13^{\mathrm{ns}}$ & Nestedness & $0.12^{\mathrm{ns}}$ \\
\hline
\end{tabular}

Note: BD, bulk density; SWC, soil water content; Pava, available phosphorus; Kava, available potassium; TNV, total neutralizing value; BR, basal respiration; SIR, substrate induced respiration. EC, electrical conductivity; ${ }^{\text {ns }}$, non-significant; ${ }^{*}$ indicates the significance at $P<0.05$ level. 

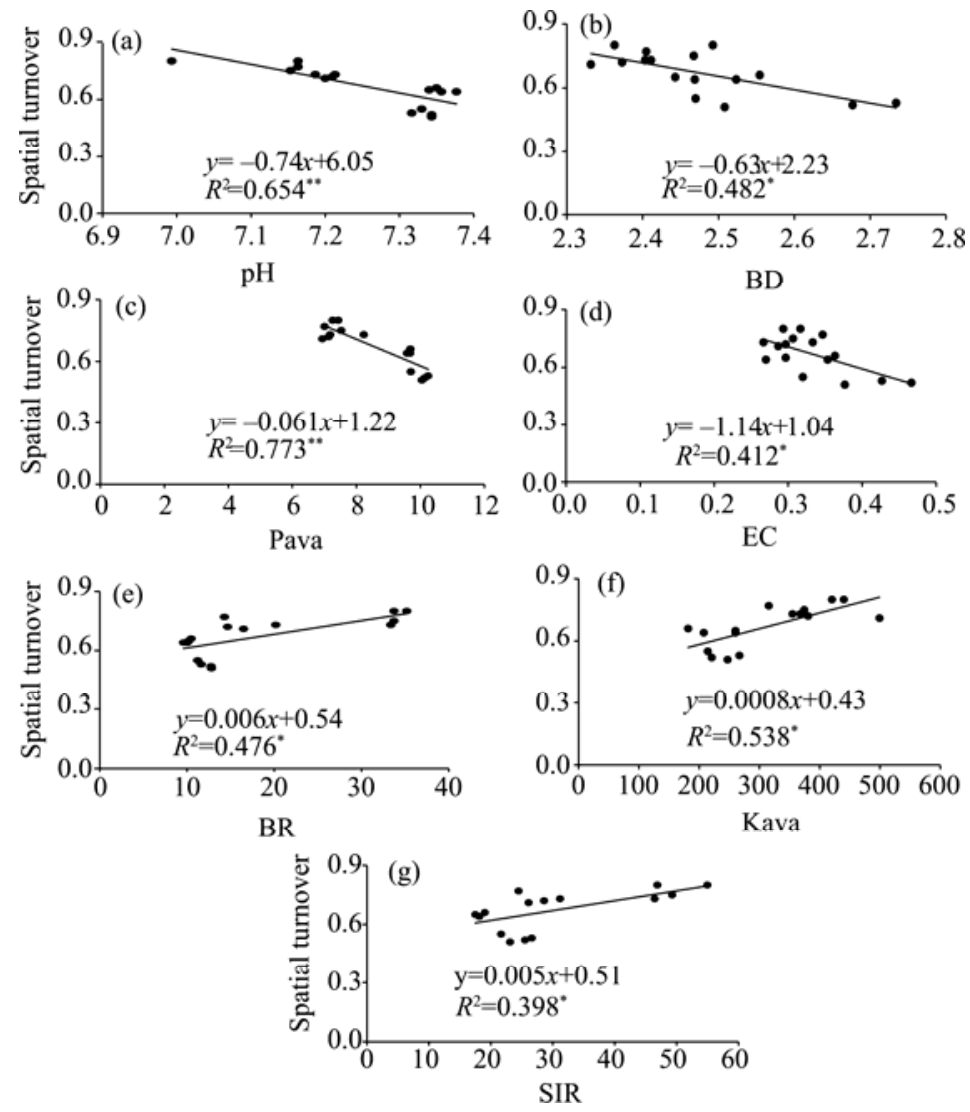

Fig. 3 Linear regressions between spatial turnover of plant species and soil properties. ${ }^{*}$ and ${ }^{* *}$ indicate significances at $P<0.05$ and $P<0.01$ levels, respectively. BD, bulk density; Pava, available phosphorus; EC, electrical conductivity; BR, basal respiration; Kava, available potassium; SIR, substrate induced respiration.
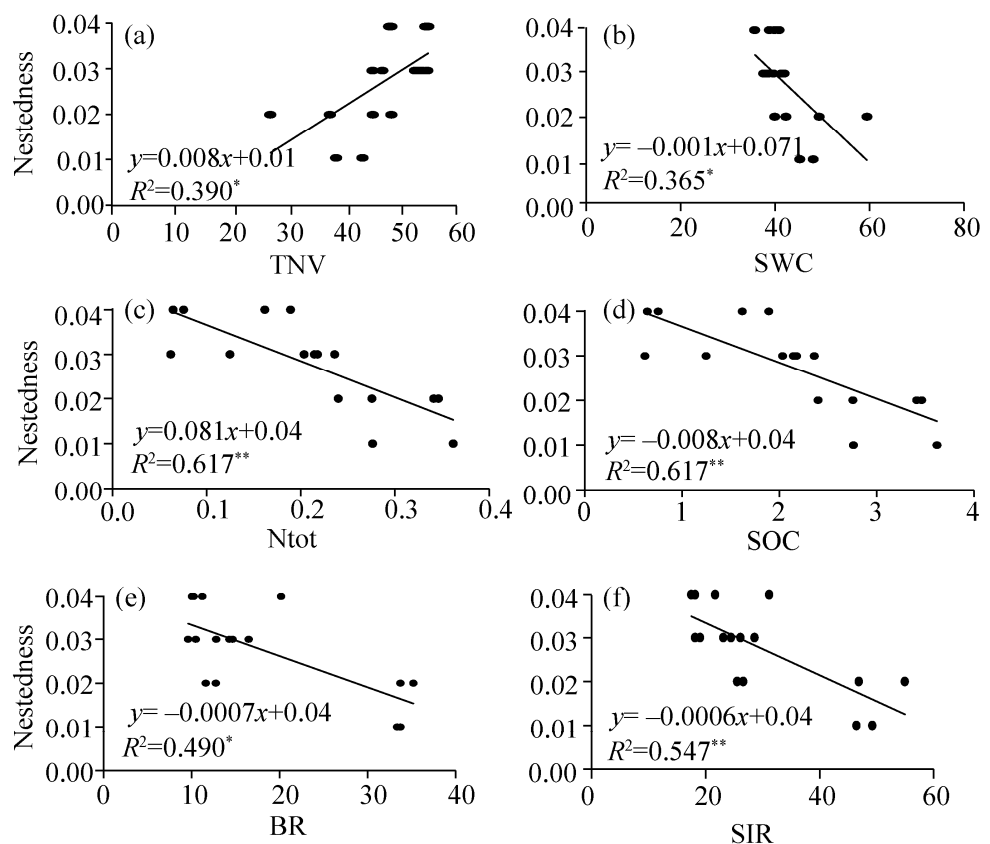

Fig. 4 Linear regressions between nestedness of plant species and soil properties. ${ }^{*}$ and ${ }^{* *}$ indicate significances at $P<0.05$ and $P<0.01$ levels, respectively. TNV, total neutralizing value; SWC, water content; TN, total nitrogen; SOC, soil organic carbon; BR, basal respiration; SIR, substrate induced respiration. 


\section{Discussion}

\subsection{Effects of management and climatic conditions on soil properties}

We found that some soil attributes were influenced by climatic conditions, while others responded to conservation measures. For instance, $\mathrm{pH}$ was probably mainly influenced by climatic conditions and showed significantly lower values in more humid Dalab region than in Koshk region. However, we cannot exclude that the higher organic matter content in soils of Dalab has stimulated the microbial activity, in particular respiration, which has led to enhanced carbon dioxide production and the formation of carbonic acid (Brady and Weil, 2008).

Similarly, soil Kava was higher in semi-arid Dalab region than in arid Koshk region, whereas the reverse was observed for Pava. In accordance, Sardans and Peñuelas (2007) emphasized the influence of climatic conditions, especially drought, in modifying soil phosphorus and potassium accumulation patterns in Mediterranean woodlands.

TN and SOC values were higher in more humid Dalab region than in arid Koshk region. Accordingly, climatic conditions influence soil organism activities, which play an important role in improving soil nutrient cycle (Frossard et al., 2000). For example, temperature affects the decomposition of organic matter and thus influences the physical, chemical, and biological soil characteristics (von Lutzow and Kogel-Knabner, 2009). Therefore, the higher SOC content in Dalab region is likely related to soil nutrient availability and thus plays an important role in soil fertility (Bationo et al., 2006). The decrease in nitrogen and organic carbon in unmanaged sites was consistent with the result that human disturbances and site degradation decreased the amount of organic matter and soil nutrients (Dahlgren et al., 2003; Heydari et al., 2014). Higher cover of woody and herbaceous species in managed sites protects soils from erosion (Mekuria and Aynekulu, 2013), while degradation agents such as livestock grazing in unmanaged Koshk region decrease plant biomass accumulation, which in turn affects soil fertility (Savadogo et al., 2007).

EC was higher in Koshk region than in Dalab region and unmanaged plots were associated with higher EC values in Koshk region. Some disturbances, such as overgrazing or tree cutting, reduce the protection of soil by vegetation and tend to dry out the soil surface and increase EC (Binkley and Fisher, 2012), a process that is especially pronounced in arid and semi-arid regions (Pan et al., 2014). This explanation also holds for the soil water content, which is higher in managed than in unmanaged areas (Kidron and Gutschick, 2013).

BD was higher in unmanaged than in managed sites although the difference was only significant in Koshk region. It is well known that soil compaction that is induced by overgrazing and low SOC increases BD (Li et al., 2011, Chaudhari et al., 2013) as observed in Koshk region.

Finer soil particles (i.e., clay and silt contents) were significantly higher in managed than in unmanaged sites, while sand was higher in unmanaged ones. Due to a higher percentage of bare soil and a lower vegetation cover, soils of unmanaged sites are more exposed to run off and erosion favoring the loss of silt and clay particles (Tessema et al., 2011).

TNV (lime percentage) was higher in unmanaged sites than in managed ones in both arid and semi-arid climates. Accordingly, Celik (2005) showed that the amount of lime increased with forest degradation and land-use change, particularly from forestland to agriculture. Changes in the content of soil lime can also be influenced by other factors such as SOC, biological activities (soil respiration) and $\mathrm{CO}_{2}$ pressure. Indeed, higher amounts of soil organic matter enhance $\mathrm{CO}_{2}$ pressure due to higher heterotrophic and autotrophic respirations and then increase carbonate dissolution (Brady and Weil, 2008).

\subsection{Soil biological variables}

BR and SIR in Dalab region were higher than those obtained from Koshk region. More abundant precipitations and lower temperatures in semi-arid Dalab region compared to arid Koshk region are favorable to vegetation development and thus increase soil organic matter (Binkley and Fisher, 2012). This process promotes microorganism activities, which can explain the higher BR and SIR values. This result is consistent with the findings of Sardans and Peñuelas (2005), who found that drought reduces soil enzyme activity in a Mediterranean oak forest. On the contrary, 
mesic climatic conditions are favorable to the activity of soil organisms (e.g., Qiu et al., 2005). The same process applies to explain the higher BR and SIR values measured in managed plots compared to unmanaged plots. Indeed, the lower vegetation cover in unmanaged areas caused by human disturbances led to a lower organic matter content and reduced respiration values (Cheng et al., 2013).

\subsection{Alpha, beta and gamma diversities and beta diversity components}

Alpha and gamma diversity values as well as both components of beta diversity (turnover and nestedness) were significantly affected by management type and climatic conditions and, to a lesser degree, by the interaction between these two variables. This is in accordance with the observations that changes in climatic and management conditions influence species occurrence, diversity and distribution in various ecosystems (Adler and Levine, 2007; van der Putten et al., 2013), particularly in arid and semi-arid rangelands (Erfanzadeh et al., 2015) .

However, our results clearly indicated that management had a major influence on alpha, beta and gamma diversities (Fig. 2a), whereas climatic conditions had no significant effect in the unmanaged Mediterranean ecosystems, which is contrary to the results of some previous studies (e.g., Rodriguez et al., 2017). Conservation management positively affected the different components of species diversity in our study sites likely because it provided sufficient opportunities for vegetation rehabilitation and plant community reconstruction (Miura et al., 2003; Coetzee et al., 2014) as well as preservation of native plant species diversity (Cox and Underwood, 2011).

The fact that beta and gamma diversities were not influenced by climatic conditions when there are no conservation measures indicates that the role of climate on vegetation composition and diversity is considerably reduced compared to the influence of anthropogenic disturbances. In fact, gamma diversity, which corresponds to the number of species in each region, peaked at 65 and 50 in managed Dalab and Koshk regions, respectively, whereas alpha diversity was approximately the same (24 and 25 respectively in MD and MK). Beta diversity, which represents the difference between the plots diversity (alpha), is therefore of 41 species for Dalab and 25 for Koshk. This indicates that beta diversity in managed areas of both regions has a similar (Korshk) or a higher (Dalab) contribution to total diversity than alpha diversity. The reduction of the negative impacts of degradation agents by the conservation management strategy resulted not only in a higher diversity at the plot level (alpha diversity; Erfanzadeh et al., 2015) but also increased species composition at the larger scales (Hermy and Verheyen, 2007). Our results are consistent with the findings of Tang et al. (2011), who observed a significant positive effect of conservation management on plant species diversity and those of Erfanzadeh et al. (2015), who showed that conservation management can increase plant diversity at the regional scale in arid regions.

Our results emphasize the major contribution of spatial turnover in beta diversity in comparison to nestedness whose contribution was limited in all treatments. These results imply that the variation in species assemblages in the studied regions is less explained by the presence of subsets of species from richer sites than by the high degree of species replacement from one location to the other (Baselga, 2010). First, the more favorable environmental conditions of Dalab region can explain its higher turnover rate compared to Koshk region because better soil qualities can positively affect plant species distribution and migration (Harrison et al., 2006; LaManna et al., 2017) and result in increased turnover. Second, the clear influence of conservation measures in both areas suggests that they should be applied more extensively rather than limited to the richest sites (Balsega, 2010).

\subsection{Relationships between oak canopy cover, soil properties, and diversity components}

Overstory canopy cover is an important ecological characteristic of Zagros oak forests, which was significantly reduced in disturbed areas (Heydari et al., 2014). Previous studies indicated that canopy cover controls the biological, physical, and chemical soil properties as well as the herbaceous coverage, which in turn, influences the seedling recruitment and development (Caldeira et al., 2014; Moradi et al., 2017).

Our results show that oak canopy cover was positively correlated with silt, $\mathrm{pH}$, Kava, and alpha 
diversity, while it was negatively correlated with turnover (Table 3). The higher organic matter content in soils under a more developed canopy cover can improve the cation exchange capacity and thus increase the soil $\mathrm{pH}$ (Dahlgren et al., 2003). Oak trees, due to their deep rooting system, can bring up nutrients from lower soil layers where they can be recycled via leaf litter, a process that can explain higher soil K content with increasing canopy cover (Moreno et al., 2007).

The canopy cover and litter, by creating a suitable microclimate and by limiting leaching, play an important role in seed storage of plant species and thus increase the diversity of plant species (Arriaga and Mercado, 2004; Heydari et al., 2013a). This can explain the positive relationship between oak canopy cover and alpha diversity of plant species. As already observed by Heydari et al. (2015) in the same region, human degradation, and lack of protective measures significantly and negatively affect overstory canopy, which, in turn, decrease species diversity.

In contrast, the negative correlation observed between oak canopy cover and turnover of plant species could reflect the modification of the microclimatic conditions below canopy, particularly light availability, which is beneficial to some shade-tolerant species but detrimental to many light-demanding plants (Benítez et al., 2015). Sabatini et al. (2014) proposed that ecological factors driving species composition and turnover, like canopy cover, forest structure, or topography, are system-specific and thus vary according to forest types.

Species turnover is negatively correlated with $\mathrm{BD}, \mathrm{EC}, \mathrm{pH}$, and Pava, but positively with Kava, $\mathrm{BR}$, and SIR. Turnover means the continuous or sudden replacement of species along an environmental gradient, and that removal or replacement is controlled by environmental variables and competition (Baselga, 2010; Lafage et al., 2015). Previous studies have shown that the reduction of habitat quality could lead to the elimination of most sensitive and non-resistant species (extinction) or species with narrow ecological niche range (Tilman and Lehman, 2001). In contrast, the improvement of soil conditions linked to conservation management can cause increased migration, development and distribution of species (Harrison et al., 2006; LaManna et al., 2017) and may increase the turnover.

Nestedness is observed when species of a specific habitat are a subset of species of a richer habitat (in term of species), and is usually explained by species extinction or selective migration (Baselga, 2010; Calderón-Patrón, et al., 2013). In our study, nestedness is significantly and positively related to TNV, and negatively related to SWC, SOC, TN, BR, and SIR. Changes in these factors can lead to limitation in ecological niches, for instance, highly calcareous soils are not adapted to lime-intolerant species, and can increase the nestedness due to extinction of species (Barnes et al., 1997). In contrast, more fertile soils (e.g., with higher nitrogen, phosphorous, potassium or SOC contents) may increase the competition and species replacement, which can lead to a higher turnover.

Given that turnover was by far a greater contributor to total beta diversity than nestedness, our results support the hypothesis that site productivity (Harrison et al., 2006; Zemunik et al., 2016; LaManna et al., 2017) and environmental heterogeneity (Chase and Leibold, 2002; Veech and Crist, 2007; Stegen et al., 2013) promote beta diversity.

\section{Conclusions}

Our results indicate that conservation management results in positive changes in the physical, chemical, and biological soil properties as well as in canopy cover of oak trees, which improve plant species diversity in both studied regions. This confirms the effectiveness of conservation management to independently increase plant species diversity of the climatic conditions although we have noted a more pronounced effect in the less arid area. More specifically, this study has shown the major contribution of beta diversity on gamma diversity, especially in semi-arid region, because of a higher heterogeneity of vegetation in this area.

Knowledge of the contribution of the components of beta diversity can be a valuable guide for managers in adopting appropriate management decisions. The high spatial turnover and the low importance of nestedness observed in this study imply that conservation measures should be applied to a large number of sites of various qualities rather than to a limited number of the 
richest sites. Besides, the negative correlation between oak cover and turnover suggests that oak forests could benefit from a silviculture aiming at enhancing micro-environmental heterogeneity, such as the creation of gaps, in order to promote species conservation and diversity.

\section{Acknowledgements}

Ilam University is kindly acknowledged for its financial support for this research work. We would like to thank Mr. Masoud HAMIDI for his guidance in soil analysis.

\section{References}

Adler P B, Levine J M. 2007. Contrasting relationships between precipitation and species richness in space and time. Oikos, 116(2): 221-232.

Alef K, Nannipieri P. 1995. Methods in Applied Soil Microbiology and Biochemistry. London: Academic Press, 576.

Anderson J P E, Domsch K H. 1978. A Physiological method for the quantitative measurement of microbial biomass in soils. Soil Biology and Biochemistry, 10(3): 215-221.

Arriaga L, Mercado C. 2004. Seed bank dynamics and tree-fall gaps in a northwestern Mexican Quercus-Pinus forest. Journal of Vegetation Science, 15(5): 661-668.

Auyeung D S N, Suseela V, Dukes J S. 2013. Warming and drought reduce temperature sensitivity of nitrogen transformations. Global Change Biology, 19(2): 662-676.

Barnes B V, Zak D R, Spurr S H, et al. 1997. Forest Ecology. New York: John Wiley and Sons Inc., 792.

Baselga A. 2010. Partitioning the turnover and nestedness components of beta diversity. Global Ecology and Biogeography, 19(1): 134-143.

Baselga A, Orme C D L. 2012. Betapart: an R package for the study of beta diversity. Methods in Ecology and Evolution, 3(5): 808-812.

Bationo A, Kihara J, Vanlauwe B, et al. 2007. Soil organic carbon dynamics, functions and management in West African agro-ecosystems. Agricultural Systems, 94(1): 13-25.

Behbahani S M, Moradi M, Basiri R, et al. 2017. Sand mining disturbances and their effects on the diversity of arbuscular mycorrhizal fungi in a riparian forest of Iran. Journal of Arid Land, 9(6): 837-849.

Benítez A R, Prieto M, Aragón G. 2015. Large trees and dense canopies: key factors for maintaining high epiphytic diversity on trunk bases (bryophytes and lichens) in tropical montane forests. Forestry, 88(5): 521-527.

Binkley D, Fisher R F. 2012. Ecology and Management of Forest Soils (4 $4^{\text {th }}$ ed.). New York: Wiley, 362.

Black C A. 1986. Methods of Soil Analysis, Part 1. Madison: Soil Science Society of America, 545-566.

Blake G R, Hartge K H. 1986. Bulk density. In: Klute A. Methods of Soil Analysis: Part 1—Physical and Mineralogy Methods ( $2^{\text {nd }}$ ed.). Madison: Soil Science Society of America, 363-376.

Bouyoucos G J. 1962. Hydrometer method improved for making particle size analysis of soils. American Society of Agronomy Journal, 54(5): 44-46.

Brady N C, Weil R R. 2008. The Nature and Properties of Soils (14 $4^{\text {th }}$ ed.). New Jersey: Prentice Hall, 975.

Bray R H, Kurtz L T. 1945. Determination of total, organic, and available forms of phosphorus in soils. Soil Science, 59(1): 39-45.

Bremner J M. 1996. Nitrogen—Total. In: In: Sparks D L, Page A L, Helmke P A, et al. Methods of Soil Analysis: Part 3 - Chemical Methods. Madison: Soil Science Society of America, 1085-1122.

Caldeira M C, Ibáñez I, Nogueira C, et al. 2014. Direct and indirect effects of tree canopy facilitation in the recruitment of Mediterranean oaks. Journal of Applied Ecology, 51(2): 349-358

Calderón-Patrón J M, Moreno C E, Pineda-López R, et al. 2013. Vertebrate dissimilarity due to turnover and richness differences in a highly beta-diverse region: the role of spatial grain size, dispersal ability and distance. PLoS ONE, 8(12): e82905.

Celik I. 2005. Land-use effects on organic matter and physical properties of soil in a southern mediterranean highland of Turkey. Soil and Tillage Research, 83(2): 270-277.

Chase J M, Leibold M A. 2002. Spatial scale dictates the productivity-biodiversity relationship. Nature, 416(6879): 427-430.

Chaudhari P R, Ahire D V, Ahire V D, et al. 2013. Soil bulk density as related to soil texture, organic matter content and available total nutrients of coimbatore soil. International Journal of Scientific and Research Publications, 3(2): 1-8.

Chávez V, Macdonald S E. 2012. Partitioning vascular understory diversity in mixed wood boreal forests: The importance of mixed canopies for diversity conservation. Forest Ecology and Management, 271: 19-26. 
Cheng F, Peng X, Zhao P, et al. 2013. Soil microbial biomass, basal respiration and enzyme activity of main forest types in the Qinling Mountains. PLoS ONE, 8(6): e67353.

Coetzee B W T, Gaston K J, Chown S L. 2014. Local scale comparisons of biodiversity as a test for global protected area ecological performance: a meta-analysis. PLoS ONE, 9(8): e105824.

Cox R L, Underwood E C. 2011. The importance of conserving biodiversity outside of protected areas in Mediterranean ecosystems. PLoS ONE, 6(1): e14508.

Crist T O, Veech J A, Gering J C, et al. 2003. Partitioning species diversity across landscapes and regions: a hierarchical analysis of $\alpha, \beta$, and $\gamma$ diversity. The American Naturalist, 162(6): 734-743.

Dahlgren R A, Horwath W R, Tate K W, et al. 2003. Blue oak enhance soil quality in California oak woodlands. California Agriculture, 57(2): 42-47.

Erfanzadeh R, Omidipour R, Faramarzi M. 2015. Variation of plant diversity components in different scales in relation to grazing and climatic conditions. Plant Ecology \& Diversity, 8(4): 537-545.

Eycott A E, Watkinson A R, Dolman P M. 2006. Ecological patterns of plant diversity in a plantation forest managed by clearfelling. Journal of Applied Ecology, 43(6): 1160-1171.

Famiglietti J, Rudnicki J, Rodell M. 1998. Variability in surface moisture content along a hillslope transect: rattlesnake Hill, Texas. Journal of Hydrology, 210(1-4): 259-281.

Fathizadeh O, Hosseini S M, Zimmermann A, et al. 2017. Estimating linkages between forest structural variables and rainfall interception parameters in semi-arid deciduous oak forest stands. Science of the Total Environment, 601-602: $1824-1837$.

Feng C, Ma Y, Fu S, et al. 2017. Soil carbon and nutrient dynamics following cessation of anthropogenic disturbances in degraded subtropical forests. Land Degradation \& Development, 28(8): 2457-2467.

Frossard E, Condorn L M, Oberson A, et al. 2000. Processes governing phosphorus availability in temperate soils. Journal of Environmental Quality, 29(1): 15-23.

Harrison S, Davies K F, Saford H D, et al. 2006. Beta diversity and the scale-dependence of the productivity-diversity relationship: a test in the Californian serpentine flora. Journal of Ecology, 94(1): 110-117.

Hermy M, Verheyen K. 2007. Legacies of the past in the present-day forest biodiversity: a review of past land-use effects on forest plant species composition and diversity. Ecological Research, 22(3): 361-371.

Heydari M, Poorbabaei H, Esmaelzade O, et al. 2013a. Germination characteristics and diversity of soil seed banks and above-ground vegetation in disturbed and undisturbed oak forests. Forest Ecosystems (Forest Science and Practice), 15(4): 286-301.

Heydari M, Poorbabaei H, Salehi A, et al. 2013b. Application of two-step clustering methods to investigate effects of oak forests conservative management of Ilam city on soil properties. Iranian Journal of Forest and Poplar Research, 21(2): 329-343.

Heydari M, Poorbabaei H, Bazgir M, et al. 2014. Earthworms as indicators for different forest management types and human disturbance in llam oak forest, Iran. Folia Forestalia Polonica, Series A, 56(3): 121-134.

Heydari M, Pourbabaei H, Esmailzadeh O. 2015. The effects of habitat characteristics and human destructions on understory plant species biodiversity and soil in Zagros forest ecosystem. Journal of Plant Researches, 28(3): 535-548.

Heydari M, Faramarzi M, Pothier D. 2016. Post-fire recovery of herbaceous species composition and diversity, and soil quality indicators one year after wildfire in a semi-arid oak woodland. Ecological Engineering, 94: 688-697.

Heydari M, Omidipour R, Abedi M, et al. 2017. Effects of fire disturbance on alpha and beta diversity and on beta diversity components of soil seed banks and aboveground vegetation. Plant Ecology and Evolution, 150(3): 247-256.

Kalra Y P, Maynard D G. 1991. Methods manual for forest soil and plant analysis. Forestery Canada, Northwest Region, Northern Forgery Centre. Edmonton, Alberta. Information Report. NOR-X-311.

Kardol P, Cregger M A, Campany C E, et al. 2010. Soil ecosystem functioning under climate change: plant species and community effects. Ecology, 91(3): 767-781.

Kidron G J, Gutschick V P. 2013. Soil moisture correlates with shrub-grass association in the Chihuahuan Desert. Catena, 107: 71-79.

Kooch Y, Jalilvand H, Bahmanyar M A, et al. 2007. Ecological distribution of Indicator species and effective edaphical factors on the northern Iran lowland forests. Journal of Applied Science, 7(11): 1475-1483.

Lafage D, Maugenest S, Bouzille J B, et al. 2015. Disentangling the influence of local and landscape factors on alpha and beta diversities: opposite response of plants and ground-dwelling arthropods in wet meadows. Ecological Research, 30(6): 1025-1035.

LaManna J A, Blote R T, Burkle L A, et al. 2017. Negative density dependence mediates biodiversity-productivity relationships across scales. Nature Ecology \& Evolution, 1: 1107-1115. 
Lande R. 1996. Statistics and partitioning of species diversity, and similarity among multiple communities. Oikos, 76(1): 5-13.

Li Y, Zhao H, Zhao X, et al. 2011. Effects of grazing and livestock exclusion on soil physical and chemical properties in desertified sandy grassland, Inner Mongolia, northern China. Environmental Earth Sciences, 63(4): 771-783.

Mekuria W, Aynekulu E. 2013. Exclosure land management for restoration of the soils in degraded communal grazing lands in northern Ethiopia. Land Degradation \& Development, 24(6): 528-538.

Mirzaei J, Moradi M. 2017. Relationships between flora biodiversity, soil physiochemical properties, and arbuscular mycorrhizal fungi (AMF) diversity in a semi-arid forest. Plant Ecology and Evolution, 150(2): 151-159.

Miura S, Yoshinaga S, Yamada T. 2003. Protective effect of floor cover against soil erosion on steep slopes forested with Chamaecyparis obtusa (hinoki) and other species. Journal of Forest Research, 8(1): 27-35.

Mohadjer M M. 2005. Silviculture. Tehran: Tehran University Press, 387.

Moradi M, Imani F, Naji H R, et al. 2017. Variation in soil carbon stock and nutrient content in sand dunes after afforestation by prosopis juliflora in the Khuzestan province (Iran). Forest-Biogeosciences and Forestry, 10(3): 585-589.

Moreno G, Obrador J J, Garcia A. 2007. Impact of evergreen oaks on soil fertility and crop production in intercropped dehesas. Agriculture, Ecosystems \& Environment, 119(3-4): 270-280.

Nelson D W, Sommers L E. 1982. Total carbon, organic carbon, and organic matter. In: Sparks D L, Page A L, Helmke P A, et al. Methods of Soil Analysis: part 3-Chemical Methods. Madison: Soil Science Society of America, 961-1010.

Onyekwelu J C, Mosandl R, Stimm B. 2006. Productivity, site evaluation and state of nutrition of Gmelina arborea plantations in Oluwa and Omo forest reserves. Forest Ecology and Management, 229(1-3): 214-227.

Pan Y X, Wang X P, Li X R, et al. 2014. The influence of Caragana korshinskii shrub on soil and hydrological properties in a revegetation-tabilized desert ecosystem. Hydrological Sciences Journal, 59(10): 1925-1934.

Parma R, Jouybari S S. 2010. Impact of physiographic and human factors on crown cover and diversity of woody species in the Zagros forests (Case study: Ghalajeh forests, Kermanshah province). Iranian Journal of Forest and Poplar Research, 18(4): $539-555$.

Qiu S, McComb A J, Bell R W, et al. 2005. Response of soil microbial activity to temperature, moisture, and litter leaching on a wetland transect during seasonal refilling. Wetlands Ecology and Management, 13(1): 43-54.

R Core Team. 2013. R: A Language and Environment for Statistical Computing. Vienna: Foundation for Statistical Computing.

Raunkiaer C. 1934. The Life Forms of Plant and Statistical Plant Geography. Oxford: The Clarendon Press, 721.

Sabatini F M, Burrascano S, Tuomisto H, et al. 2014. Ground layer plant species turnover and beta diversity in Southern-European Old-Growth Forests. PLoS ONE, 9(4): e95244.

Sagheb-Talebi K S, Sajedi T, Pourhashemi M. 2014. Forests of Iran. New York: Springer Netherlands, 149.

Salehi A, Söderberg U, Eriksson L O, et al. 2013. Impacts of forest-based activities on woodland characteristics. Caspian Journal of Environmental Sciences, 11(2): 161-176.

Sardans J, Peñuelas J. 2005. Drought decreases soil enzyme activity in a Mediterranean Quercus ilex L. forest. Soil Biology and Biochemistry, 37(3): 455-461.

Sardans J, Peñuelas J. 2007. Drought changes phosphorus and potassium accumulation patterns in an evergreen Mediterranean forest. Functional Ecology, 21(2): 191-201.

Savadogo P, Sawadogo L, Tiveau T. 2007. Effects of grazing intensity and prescribed fire on soil physical and hydrological properties and pasture yield in the savanna woodlands of Burkina Faso. Agriculture, Ecosystems \& Environments, 118(1-4): 80-92.

Schulze E D, Aas D, Grimm G W, et al. 2016. A review on plant diversity and forest management of European beech forests. European Journal of Forest Research, 135(1): 51-67.

Sheklabadi M, Khademi H, Eghbal M K, et al. 2007. Effects of climate and long-term grazing exclusion on selected soil biological quality indicators rangelands of Central Zagros. Journal of Water and Soil Science, 11(41): 103-116.

Stegen J C, Freestone A L, Crist T O, et al. 2013. Stochastic and deterministic drivers of spatial and temporal turnover in breeding bird communities. Global Ecology and Biogeography, 22(2): 202-212.

Steinweg J M, Dukes J S, Paul E A, et al. 2013. Microbial responses to multi-factor climate change: effects on soil enzymes. Frontier in Microbiology, 146: 1-11.

Strandberg B, Kristiansen S M, Tybirk K. 2005. Dynamic oak-scrub to forest succession: effects of management on understorey vegetation, humus forms and soils. Forest Ecology and Management, 211(3): 318-328.

Sumner M E, Miller W P. 1996. Cation exchange capacity and exchange coefficients. In: Sparks D L. Methods of Soil Analysis: part 3-Chemical Properties. Madison: Soil Science Society of America, 1201-1230.

Tang Z, Fang J, Sun J, et al. 2011. Effectiveness of protected areas in maintaining plant production. PLoS ONE, 6: e19116.

Tárrega R, Calvo L, Taboada Á, et al. 2009. Abandonment and management in spanish dehesa systems: Effects on soil features 
and plant species richness and composition. Forest Ecology and Management, 257(2): 731-738.

Tessema Z K, de Boer W F, Baars R M T, et al. 2011. Changes in soil nutrients, vegetation structure and herbaceous biomass in response to grazing in a semi-arid savanna of Ethiopia. Journal of Arid Environments, 75(7): 662-670.

Tilman D, Lehman C. 2001. Human-caused environmental change: impacts on plant diversity and evolution. Proceedings of the National Academy of Sciences, 98(10): 5433-5440.

Toure T, Ge J W, Zhou J W. 2015. Interactions between soil characteristics, environmental factors, and plant species abundance: A case study in the Karst Mountains of Longhushan Nature Reserve, southwest China. Journal of Mountain Science, 12(4): 943-960.

van der Putten W H, Bardgett R D, Bever J D, et al. 2013. Plant-soil feedbacks: the past, the present and future challenges. Journal of Ecology, 101(2): 265-276.

Veech J A, Crist T O. 2007. Habitat and climate heterogeneity maintain beta-diversity of birds among landscapes within ecoregions. Global Ecology and Biogeography, 16(5): 650-656.

von Lützow M, Kögel-Knabner I. 2009. Temperature sensitivity of soil organic matter decomposition-What do we know? Biology and Fertility of Soils, 46(1): 1-15.

Wang G, Zhou Y, Xu X, et al. 2013. Temperature sensitivity of soil organic carbon mineralization along an elevation gradient in the Wuyi Mountains, China. PLoS ONE, 8(1): e53914.

Wang P, Sun R, Hu J, et al. 2007. Measurements and simulation of forest leaf area index and net primary productivity in Northern china. Journal of Environmental Management, 85(3): 607-615.

Wilson S, Tilman D D. 2002. Quadratic variation in old-field species richness along gradients of disturbance and nitrogen. Ecology, 83(2): 492-504.

Yacht A L V, Barrioz S A, Keyser P D, et al. 2017. Vegetation response to canopy disturbance and season of burn during oak woodland and savanna restoration in Tennessee. Forest Ecology and Management, 390: 187-202.

Zemunik G, Turner B L, Lambers H, et al. 2016. Increasing plant species diversity and extreme species turnover accompany declining soil fertility along a long-term chronosequence in a biodiversity hotspot. Journal of Ecology, 104(3): $792-805$.

Zhang Y, Zhang S, Ma K, et al. 2014. Woody species diversity in forest plantations in a mountainous region of Beijing, China: effects of sampling scale and species selection. PLoS ONE, 9(12): e115038. 